С. Г. Качурін, кандидат юридичних наук, доцент, доцент кафедри конституційного права, Східноукраїнський національний університет ім. Володимира Даля, м. Сєвєродонецьк, Луганська обл.

М. В. Семеніхін, директор, Луганський науково-дослідний експертно-криміналістичний центр МВС України, м. Рубіжне, Луганська обл.

\title{
ПОДОЛАННЯ ПРОТИДІЇ ПІД ЧАС ПРОВЕДЕННЯ СУДОВОЇ ПОЧЕРКОЗНАВЧОЇ ЕКСПЕРТИЗИ: СИСТЕМИ ТАКТИЧНИХ ПРИЙОМІВ
}

\begin{abstract}
Мета статті - аналіз теоретичних питань і розроблення практичних рекомендацій із тактики відібрання експериментальних зразків почерку та підписів в умовах протидії перевірюваних осіб під час проведення судових почеркознавчих експертиз. Методологія. Методологічну основу становлять загальні закони та категорії теорії пізнання, зокрема положення матеріалістичної діалектики про пізнання соціальних процесів і явищ, пов'язаних із досліджуваними проблемами. У процесі розгляду теми також застосовувалися історико-правовий метод, яким проаналізовано генезу розроблення тактико-технологічних засад проведення слідчих дій, теоретичні напрацювання криміналістичних аспектів протидії при проведенні судових почеркознавчих експертиз; системно-структурним і порівняльним встановлено сутність тактики проведення судових почеркознавчих експертиз, з'ясовано прийоми подолання протидії перевірюваних осіб проведенню почеркознавчої експертизи, а також групування їх в системи, запропоновано рекомендації щодо їх застосування; соціологічний метод (анкетування) застосовано для опитування слідчих та експертів за спеціально розробленою анкетою; статистичним методом (групування відомостей, аналіз кількісних показників) узагальнено дані за результатами аналізу висновків експертів, протоколів відібрання зразків почерку та підписів; експериментальним проведено експерименти з відтворення чужих підписів різними категоріями осіб. Наукова новизна зумовлена започаткуванням заснованого на результатах проведеного авторами експерименту тактичного прийому подолання протидії перевірюваної особи в разі повідомлення неправдивої інформації про незнання цією особою транскрипції підпису конкретної людини, що полягає в наданні особі досліджуваного підпису для короткочасного візуального його огляду. Висновки. У результаті дослідження, зокрема, з'ясовано, що залежно від слідчої ситуації, яка склалася, системи тактичних прийомів відібрання зразків спрямовані: на встановлення обставин та умов виконання рукопису; одержання зразків почерку перевірюваної особи в ситуації можливої ії відмови; спілкування з такою особою і вплив на неї у процесі відібрання зразків; подолання протидії перевірюваної особи. При цьому тактичні прийоми подолання протидії перевірюваної особи передбачають: за відмови від надання експериментальних зразків почерку та підписів - використання прийомів психологічного впливу та логічного переконання; у разі спотворення перевірюваним свого почерку - прискорення темпу написання та збільшення тривалості відібрання зразків; якщо повідомлено неправдиву інформацію про незнання перевірюваним транскрипції підпису конкретної людини - надання досліджуваного підпису для короткочасного візуального його огляду.

Ключові слова: судова почеркознавча експертиза; зразки почерку й підписів; тактика і технологія відібрання експериментальних зразків; протидія проведенню судової почеркознавчої експертизи; прогнозування слідчої ситуації; системи тактичних прийомів; психологічний контакт; моделювання обставин і умов відібрання експериментальних зразків почерку та підписів.
\end{abstract}

(C) С. Г. Качурін, М. В. Семеніхін, 2020 


\section{Вступ}

Стрімкий розвиток ринкових відносин в Україні супроводжується значним зростанням кількості документів, найважливішим реквізитом яких $є$ підпис - чи не найпоширеніший об’єкт судової почеркознавчої експертизи.

Водночас аналіз слідчої, судової та експертної практики засвідчує, що перед слідчими, суддями, адвокатами (захисниками) постають значні проблеми, коли призначаються судові почеркознавчі експертизи, пов'язані з підготовкою об'єктів, формуванням запитань, дослідженням і оцінкою висновку експерта у галузі почеркознавства.

Особливо яскраво зазначені проблеми виявляються під час підготовки порівняльних почеркових матеріалів, коли перевірювана особа протидіє проведенню почеркознавчої експертизи. Це призводить до ії низької результативності, а то й відмови від неї. А отже на часі опрацювання сучасних комплексних наукових і методичних розробок та рекомендацій із питань тактики проведення судових почеркознавчих експертиз, одержання зразків почерку та підписів в умовах протидії перевірюваної особи, аби підвищити рівень спеціальної підготовки слідчих, суддів та адвокатів (захисників).

При цьому слід зважати на те, що однією із засад вітчизняного кримінального провадження визнано змагальність сторін. Тому аналіз положень і нормативних приписів Кримінального процесуального кодексу України (далі - КПК України) дає підстави стверджувати, що як сторона захисту в кримінальному провадженні адвокат (захисник) теж має певні процесуальні можливості для здійснення захисту, повноваження на активне доказування позиції захисту шляхом збирання доказів, отримання зразків для призначення судових почеркознавчих експертиз, участі в проведенні слідчих (розшукових) та інших процесуальних дій. Згідно зі ст. 245 КПК України відібрання зразків для експертизи здійснює суд або за його дорученням залучений спеціаліст. Водночас постає потреба у функціонуванні нових процесуальних методів і способів, що забезпечують реалізацію прав і свобод людини, а також нової криміналістичної методології. Для цього, вважає В. Б. Шабанов, доцільно мати необхідний тактичний і стратегічний засіб - систему технологій, що становлять композицію криміналістичного забезпечення оперативно-розшукової діяльності, розслідування, обвинувачення, захисту і судової діяльності (Shabanov, 2017, s. 10).

Окреслене визначає актуальність обраної тематики і зумовлює необхідність започаткування нових підходів до опрацювання криміналістичних засад забезпечення діяльності слідчих, суддів та адвокатів (захисників), а також розроблення системи тактичних прийомів і криміналістичних рекомендацій щодо подолання протидії перевірюваних осіб і запобігання їй, щоб забезпечити швидке і результативне вирішення завдань досудового розслідування та судового процесу під час проведення судових почеркознавчих експертиз.

Теоретичне підгрунтя цього дослідження становлять наукові праці Р. С. Бєлкіна, I. Є. Биховського, О. М. Васильєва, В. Г. Гончаренка, В. Г. Доспулова, А. В. Дулова, В. П. Колмакова, В. О. Коновалової, Ю. К. Орлова, М. І. Порубова, О. Р. Ратинова, М. В. Салтевського, М. О. Селіванова, М. Я. Сегая, О. Б. Соловйова, В. Ю. Шепітька, М. Г. Щербаковського, інших учених, окремі питання досліджуваної теми розглядали, зокрема, C. Bird, B. Found, K. Ballantyne, \& D. Rogers (2010); C. Bird, \& B. Found (2016); R. Huber, \& A. Headrick (2017); R. R. Gupta, \& N. Ravi (2018); M. W. Thomas, \& S. K. Rajan (2019). Їх зусиллями розроблялися основи використання спеціальних знань у різних видах судочинства, створювалася теорія судової експертизи, запроваджувалися ідеї, що 
відбивали сутність і значущість тактико-технологічних засад проведення слідчих дій, вивчення проблем протидії розслідуванню і прийомам її подолання при розгляді тактики проведення таких слідчих дій, як огляд місця події, обшук, допит.

Розкриті ними аспекти важливі для загального розуміння сутності тактико-технологічних засад проведення слідчих дій, проблем формування та використання тактичних прийомів і групування їх у системи. Але це не вичерпує всього розмаїття питань, що недостатньо визначені і неналежно теоретично обгрунтовані для ефективного проведення судової почеркознавчої експертизи і отримання зразків почерку та підписів.

Більш глибокого дослідження потребують спеціальні питання, пов'язані з комплексом теоретичних і практичних проблем із тактики проведення судової почеркознавчої експертизи та отримання зразків почерку і підписів в умовах протидії перевірюваних осіб, які ще недостатньо вивчені.

\section{Мета і завдання дослідження}

Метою статті є аналіз теоретичних питань і розроблення практичних рекомендацій із тактики відібрання експериментальних зразків почерку та підписів в умовах протидії перевірюваних осіб під час проведення судових почеркознавчих експертиз.

Для досягнення окресленої мети необхідно виконати такі завдання:

визначити передумови ефективного проведення судової почеркознавчої експертизи;

з'ясувати зумовленість тактичних прийомів відібрання експериментальних зразків для експертного дослідження на етапі підготовки судової почеркознавчої експертизи і результатів прогнозування слідчої ситуації, що склалася, поведінки перевірюваної особи;

класифікувати тактичні прийоми відібрання експериментальних зразків почерку та підписів залежно від ситуаційної обумовленості;

з'ясувати залежність систем тактичних прийомів відібрання зразків від слідчої ситуації;

виявити особливості реалізації тактичних прийомів подолання протидії перевірюваних осіб.

\section{Виклад основного матеріалу}

Швидкість і результативність вирішення завдань розслідування забезпечуються, зокрема, тактичними прийомами, що відповідають умовам конкретної ситуації і які з усіх імовірних найефективніші. При цьому диференціювання тактичних прийомів уможливлює їх вибір з аналогічних за своєю спрямованістю. Для розроблення типових систем тактичних прийомів при організації слідчих дій, зважаючи на їх специфіку, складність, а то й дискусійні визначення тактичних прийомів (Komissarov, 1987, s. 87-89; Komarkov, 1973, s. 12-13; Shepitko, 1995, s. 33), вони потребують систематизації у групи, блоки, комплекси, системи за ознаками схожості, закономірностями та механізмами дії (Konovalova, 1981, s. 42; Komissarov, 1987, s. 71), зумовлюючи необхідність започаткування єдиного класифікаційного апарату тактичних прийомів.

При цьому хибними, на наш погляд, є спроби творення єдиної універсальної системи, якою б охоплювалося все розмаїття тактичних прийомів в усіх їх проявах, оскільки з огляду на сутність класифікації така система неминуче міститиме неточності й суперечності.

Грунтуючись на вироблених наукою криміналістикою загальних положеннях, пропонуємо тактичні прийоми відібрання експериментальних зразків почерку і підписів у перевірюваної особи класифікувати за такими критеріями: 


\section{1. Етапи проведення слідчої дії:}

тактичні прийоми, використовувані в процесі підготовки до відібрання зразків: вивчення особистості особи, від якої планується відібрати експериментальні зразки почерку і підписів, для прогнозування ï поведінки під час слідчої дії, аналіз почеркових об’єктів із метою визначення факту виконання їх у незвичайній обстановці, у незвичайному стані; моделювання умов їх виконання та ін.;

тактичні прийоми, використовувані безпосередньо під час відібрання зразків почерку і підписів: прискорення або уповільнення темпу написання; надання спеціальних текстів із відповідними буквами, цифрами, словами тощо.

2. Об’єкти впливу:

тактичні прийоми, спрямовані на вплив на перевірювану особу: роз'яснення мети відібрання зразків почерку і підписів; використання факту надання показань свідків, співучасників про виконання досліджуваного тексту або підписів особою, від якої відбираються зразки, та ін.;

тактичні прийоми, спрямовані на попереднє дослідження почеркових об'єктів: аналіз почеркових об'єктів для визначення їх достатності, порівнянності, встановлення ознак спотворення перевірюваною особою свого почерку тощо.

3. Види слідчої ситуаціі:

У сприятливій ситуації співпраці перевірюваної особи за необхідності використовуються прийоми, зумовлені технологічним процесом відібрання і видом досліджуваного почеркового об’єкта (наприклад, буквений текст або цифрові записи);

У конфліктній ситуації протидії перевірюваної особи у формі відмови від надання зразків, спотворення свого почерку застосовуватимуться такі тактичні прийоми: переконання особи в хибності іï позиції; впив на позитивні складові особистості; роз'яснення обвинуваченому положень ст. 45 Кримінального кодексу України (далі - КК України) про звільнення від кримінальної відповідальності у зв’язку з дійовим каяттям і ст. 66 КК України про те, що щире каяття й активне сприяння розкриттю злочину (у нашому випадку - надання зразків почерку) є обставинами, що пом’якшують покарання; прискорення темпу письма.

4. Характер інформації, що передається перевірюваному:

тактичні прийоми, засновані на демонстрації матеріалізованої інформації: показ підозрюваному, обвинуваченому протоколів відібрання експериментальних зразків почерку і підписів від співучасників, демонстрація висновків експерта та ін.;

тактичні прийоми, засновані на повідомленні словесної, логіко-розумової інформації: повідомлення про надання показань свідками, співучасниками про відомі слідчому дані про виконання досліджуваного тексту або підписів саме особою, від якої відбираються експериментальні зразки, у певних умовах і певним способом; роз'яснення значення щирого каяття тощо.

5. Зміст:

тактичні прийоми, що визначають способи дії слідчого (операційні прийоми): вибір місця, умов, технічних засобів відібрання експериментальних зразків і фіксації слідчої дії;

тактичні прийоми, що визначають лінію поведінки слідчого (поведінкові прийоми): встановлення психологічного контакту з перевірюваною особою, виклад мети й умов відібрання зразків та ін.

Коли відбирають зразки почерку і підписів, застосовують не один тактичний прийом, а комплекс або систему взаємозв'язаних прийомів, які залежать від слідчої ситуаціï, що склалася. 
Системи тактичних прийомів проведення окремих слідчих дій мають (Komarkov, 1973) подвійну структуру: з одного боку, вони за своєю природою належать до певного виду слідчої дії (наприклад, відібрання зразків для експертного дослідження); з другого, ці системи мають підсистеми, зумовлені метою проведення конкретної слідчої дії (s. 72).

При цьому, створюючи системи тактичних прийомів окремих слідчих дій, слід зважати (Konovalova, \& Shepitko, 1997) на їх специфіку, а не на їх універсальну загальну природу. У цьому разі системи виконуватимуть широку робочу (практичну) функцію, що й визначатиме їх ефективність (s. 30).

Сукупність тактичних прийомів або слідчих дій, що мають на меті вирішення конкретного завдання розслідування, зумовлена цією метою й слідчою ситуацією, становить тактичну комбінацію (Belkin, 1997, s. 210-213). Спираючись на це стале визначення, вважаємо, що сукупність тактичних прийомів, вживаних під час відібрання експериментальних зразків почерку та підписів для експертного дослідження, створює тактичну комбінацію, метою якої є одержання репрезентативних, якісних зразків.

Специфіка відібрання експериментальних зразків почерку та підписів визначає необхідність розроблення систем тактичних прийомів, зумовлених слідчою ситуацією, що склалася, серед яких виокремимо такі:

1. Тактичні прийоми, засновані на результатах попереднього дослідження почеркових об’єктів для встановлення обставин і умов їх виконання. Мета застосування цих прийомів полягає в моделюванні обставин і умов відібрання експериментальних зразків почерку та підписів від перевірюваної особи. Цими прийоми послуговуються на підготовчій стадії відібрання зразків почерку і підписів.

Застосування системи тактичних прийомів цієї групи можна проілюструвати прикладами, коли попереднім дослідженням почеркових об’єктів фахівець може встановити, зокрема, ознаки зміни руки, якою пишуть (написання лівою рукою), наслідування друкарського тексту та ін. При цьому слідчий, готуючись до відібрання експериментальних зразків почерку та підписів, обирає найефективніші прийоми, застосування яких зумовлене властивостями почеркового матеріалу та умовами його виконання, i моделює перебіг майбутньої слідчої дії, тобто їі технологічний процес. Приміром, якщо досліджуваний почерковий об’єкт виконаний незвичною до письма рукою, відбирають експериментальні зразки почерку, виконані як лівою, так і правою рукою.

2. Тактичні прийоми, спрямовані на одержання зразків почерку перевірюваної особи в ситуації можливої її відмови. Застосовуються у процесі підготовки до судової почеркознавчої експертизи, коли в результаті вивчення особи обвинуваченого (підозрюваного) слідчий прогнозує ймовірну його відмову надати зразки для порівняння.

У цій ситуації слідчий перевірювану особу про проведення судової почеркознавчої експертизи не інформує аж до моменту винесення постанови про їі призначення. Після того як постанова винесена, слідчий поєднує це ознайомлення з відібранням експериментальних зразків почерку і підписів. При цьому чинник раптовості дає змогу уникнути виникнення установки на відмову від надання зразків.

Коли є вагомі підстави вважати, що перевірювана особа відмовиться надати зразки почерку і підписів, то як порівняльний матеріал використовують умовно-вільні зразки. Наприклад, при одержанні від обвинуваченого (підозрюваного) будь-якої заяви або клопотання у справі йому можна запропонувати оформити їх так, щоб вони максимально зіставлялися 3 досліджуваним почерковим матеріалом. Слідчий обгрунтовує необхідність саме такої форми документів, пропонує внести до реквізитів цих документів 
певні слова, цифри, які є в почерковому матеріалі досліджуваних документів. При цьому можна рекомендувати перевірюваній особі виконати текст у прописному варіанті, почерком на кшталт друкарського та іншим способом, схожим на почерк у досліджуваному документі.

3. Тактичні прийоми, спрямовані на спілкування з перевірюваною особою і вплив на неї. Їх використання дає змогу слідчому встановити психологічний контакт 3 перевірюваною особою; створити сприятливу обстановку слідчої дії; уникнути відмови від надання зразків; одержати орієнтувальну інформацію про наміри особи спотворити почерковий матеріал, який відбирається, і своєчасно запобігти ії протидії.

Для встановлення психологічного контакту з перевірюваною особою рекомендують (Ratinov, 2001, s. 197) такі прийоми:

бесіда з особою на вільну тему, з можливим повідомленням інформації про їі сім’ю, що не стосується матеріалів розслідування;

позитивна оцінка їі громадських, особистих, професійних якостей;

висловлювання співчуття і розуміння стану обвинуваченого, з'ясування умов його перебування у слідчому ізоляторі та ін.

Тактичні прийоми, спрямовані на встановлення спроби перевірюваної особи спотворити свій почерк, тісно пов'язані з участю у цій слідчій дії спеціаліста-почеркознавця. У разі виявлення ознак спотворення (уповільнення, прискорення темпу написання, зміна загальних ознак та ін.) спеціаліст негайно сповіщає про це слідчого.

У процесі вербальної взаємодії з перевірюваною особою слідчий застосовує психологічний вплив, який, на думку О. Р. Ратинова, є одним з елементів слідчої тактики (Ratinov, 2001, s. 197). Правомірний вплив має, насамперед, спонукати перевірювану особу до свідомого перегляду своєї позиції, яка суперечить інтересам слідства.

4. Тактичні прийоми, спрямовані на усунення протидії особи, від якої відбираються експериментальні зразки почерку і підписів.

Розглянуті нами раніше (Semenikhin, \& Kachurin, 2018, s. 96-105) форми і прийоми протидії осіб відбиранню експериментальних зразків почерку та підписів зумовлюють необхідність наукового розроблення спеціальних тактичних прийомів та їх систем, які дають змогу нейтралізувати протидію і досягти поставленої мети - одержання експериментальних зразків порівняння, які задовольнятимуть вимогам безсумнівності, репрезентативності і порівнянності.

Сьогодні у криміналістиці й судовому почеркознавстві не розроблено системи тактичних прийомів, спрямованих на подолання протидії перевірюваних осіб при відібранні у них експериментальних зразків почерку та підписів.

Пропонуємо такі прийоми, що можуть використовуватися ізольовано одне від одного або в поєднанні, що утворює тактичну комбінацію - подолання відмови перевірюваної особи від надання експериментальних зразків почерку та підписів:

А. У разі відмови від надання експериментальних зразків почерку та підписів застосовуються такі прийоми:

повідомляють мету цієї слідчої дії та обгрунтовують ії необхідність для встановлення обставин злочину;

пропонують особі змінити свою поведінку;

переконують у формі наказу;

доводять хибність її позиції;

роз'яснюють необхідність надання допомоги органам досудового розслідування; 
повідомляють про факт отримання показань від свідків, співучасників у справі про виконання досліджуваного тексту або підписів саме особою, від якої відбираються експериментальні зразки, у певних умовах і певним способом.

Більшість із цих прийомів засновано на психологічному впливі на особу, зважаючи на іiі позитивні якості, результатом чого незрідка є їі відмова від протидії. Якщо цей прийом не спрацьовує, застосовують інший - переконання у формі наказу як один із різновидів переконання. При цьому в деяких випадках позиція особи, яка бере участь у відібранні експериментальних зразків почерку та підписів, різко змінюється, і конфліктна ситуація перетворюється на сприятливу.

Важливе значення має тактичний прийом, пов'язаний із роз'ясненням особі, від якої відбираються експериментальні зразки почерку і підписів, хибності позиції протидії. Заснований він також на методі переконання, аби сприяти особі в тому, щоб вона розібралася в суперечливих обставинах і прийняла правильне рішення, виявила помилки, яких вона припустилася, усвідомила свою провину.

Позитивного ефекту досягають, застосовуючи тактичний прийом, що полягає в повідомленні мети цієї слідчої дії і обгрунтуванні необхідності відібрання зразків для судової почеркознавчої експертизи. Тактичний прийом, спрямований на переконання особи у сприянні органам досудового розслідування, полягає в роз'ясненні обвинуваченому положень ст. 45 і 66 КК України.

Якщо під впливом прийомів емоційного характеру особа відмовляється надати експериментальні зразки почерку та підписів, застосовують прийом логічного впливу, який полягає у використанні показань свідків, співучасників про виконання досліджуваного тексту або підписів саме перевірюваною особою.

Б. Якщо спеціаліст-почеркознавець, який бере участь у відібранні зразків, повідомляє про спробу спотворити почерк, прискорюють темп написання і збільшують тривалість відібрання зразків. Мета такого прийому - «стомити» особу, яка пише, щоб вона втратила контроль із деавтоматизації своїх рухів і внесення до почерку різних спотворень.

В. У разі повідомлення неправдивої інформації про незнання перевірюваною особою транскрипції підпису конкретної людини, коли є підозра, що досліджуваний підпис виконаний перевірюваною особою від іiі імені - особі надають досліджуваний підпис для короткочасного візуального огляду. Запропонований нами тактичний прийом не традиційний, а тому потребує окремого розгляду.

У слідчій та експертній практиці серед складних завдань і таких, що найчастіше трапляються, - дослідження підпису, виконаного від імені іншої особи з наслідуванням справжнього підпису (здебільшого на око, по пам’яті, у результаті тренування).

Водночас слід наголосити, що рекомендації фахівців стосовно виду і кількості зразків порівняння, способів їх відібрання для експертного дослідження підписів, виконаних від імені іншої особи з наслідуванням справжнього підпису, незрідка мають суперечливий характер.

Зокрема, В. Є. Бергер і О. П. Сапун рекомендують (проте не аргументуючи такий підхід) у перевірюваної особи відбирати зразки підпису і рукописного тексту. В експериментальних зразках почерку мають бути слова, в яких $є$ поєднання букв, що й у досліджуваному підписі. Перевірюваному пропонують виконати кілька зразків підписів від імені особи, підпис якої досліджується. Справжній підпис не показують, а тим паче не дають його змальовувати (Berger, \& Sapun, 1974, s. 15). О. М. Фількова для такого виду досліджень пропонує надавати експерту зразки підписів і текстів, виконаних як особа- 
ми, від імені яких виконані підписи, так і перевірюваним. Водночас підписи перевірюваних мають бути виконані не від свого імені, а від імені особи, чий підпис досліджується (Filkova, 2001, s. 89), при цьому про те, чи показувати досліджуваний підпис перевірюваному під час відібрання у нього зразків підписів від імені іншої особи, не згадується.

Отже, постають важливі для слідчої та експертної практики питання:

по-перше, який тактичний прийом застосувати слідчому, якщо перевірюваний заявляє про те, що не знає, як підписується особа, підпис якої досліджується? Чи слід обмежитися відібранням рукописного тексту, у словах якого є поєднання букв, однакових з досліджуваним підписом? А як вчинити, коли досліджуваний підпис має обмежену кількість букв або взагалі безбуквену транскрипцію? У такому разі, за наявності тільки зразків почерку, проведення ідентифікаційного дослідження практично неможливе, оскільки поєднання букв у словах і в підписі мають, як правило, різні характеристики. Адже у підписі на відміну від почерку виникають, наголошують Л. А. Вінберг і М. В. Шванкова, своєрідні побудови, з'являються спрощення букв, їх елементів та їх поєднань, прискорюється темп руху, автоматизм сягає найвищого рівня (Vinberg, \& Shvarnkova, 1977);

по-друге, чи необхідно показувати (або давати змальовувати) особі, яка перевіряється і від якої відбираються зразки підписів від імені іншої особи, справжній підпис?

Для їх розв’язання автори цієї наукової статті провели експеримент з визначення ступеня схожості справжніх і підроблених підписів, виконаних зазначеними вище трьома способами. Імітаторами виступали 120 студентів закладів вищої освіти 3 різним ступенем загальної та спеціальної пам'яті графічних зображень, що мали здібність до малювання. Кожному були показані підписи різного ступеня складності, при цьому тривалість сприйняття кожного підпису становила приблизно 5 хв. Випробувані виконували підписи: а) змалюванням без попередньої підготовки; б) змалюванням з попередньою підготовкою; в) по пам’яті через 15-20 хв після сприйняття. Результати такі.

За підробки підпису змалюванням без попередньої підготовки досягнуто близької зовнішньої схожості. Але в підписі-підробці, оскільки в такому разі йдеться про процес неавтоматичний, виявлено ознаки, які засвідчують незвичні рухи виконавця: звивистість рухів, тупі начала й закінчення рухів, втрата темпу через невиправдані зупинки писального приладу та ін. Прагнучи максимальної зовнішньої схожості, підроблювач втрачає істотні часткові ознаки, що дозволяють експертним дослідженням встановити недостовірність підпису. У результаті попереднього тренування, тобто багаторазового повторення ознак справжнього підпису, які запам'яталися (спочатку через безпосереднє зорове сприйняття, а згодом і без нього), у виконавців вироблялася письмова навичка. Унаслідок цього, виконуючи підпис від імені іншої особи, вдавалося відобразити загальні і деякі часткові ознаки підроблюваного підпису. При наслідуванні по пам'яті, як правило, також не вдається досягти повної схожості зі справжнім підписом. У цьому разі, відтворюючи підпис, підроблювач зосереджується на його загальному вигляді, не зважаючи на деякі загальні ознаки і більшість часткових.

Крім того, дослідженням експериментальних підписів, виконаних студентами всіма трьома видами наслідування, встановлено ознаки, які різняться: загальні (виробленість, форма і протяжність рухів за вертикаллю і горизонталлю, зв’язність, будова лінії рядка підпису та ін.) й окремі (ті, що властиві й ознакам почерку, а також що відбивають особливості виконання безбуквеної частини підпису: розміри кутів, ступінь кривизни дугоподібних елементів, розміщення розчерку та ін.). Установлені розбіжності дають 
змогу зробити категоричний негативний висновок про тотожність особи, яка виконала досліджуваний підпис й експериментальні зразки.

Отже, експериментально доведено необгрунтованість рекомендації В. Є. Бергера та О. П. Сапуна заборонити показувати досліджуваний підпис перевірюваній особі, оскільки для повного копіювання справжнього підпису замало лише його оглянути. Особистий досвід роботи експертом і проведені експерименти підтверджують висновок Л. Ю. Ароцкера про те, що експертна практика не знає випадків, коли б у підписі, виконаному з наслідуванням у результаті тренування, і справжніх підписах певної особи збігалися, крім загальних, усі без винятку часткові ознаки (Arotcker, 1958, s. 167).

Тому, убачається, наявні рекомендації дискусійні. 3 нашого погляду, коли перевірювана особа заявляє про те, що ӥй невідомо, як підписується особа, підпис від імені якої є досліджуваним (його конструкція, транскрипція), то їй необхідно надати для короткочасного огляду (не змальовування) вільні зразки підписів особи, від імені якої виконаний досліджуваний спірний підпис. Якщо зазначена демонстрація неможлива через відсутність вільних зразків підпису, перевірюваній особі надається підпис у досліджуваному документі - речовому доказі. Слушність цього засвідчують не тільки результати проведених експериментів, а й наукові засади почеркознавства i, зокрема, основні властивості підписів. Підпис як почерковий матеріал має такі ідентифікаційні властивості, як індивідуальність і стійкість. Процес формування підпису, наголошують Л. А. Вінберг і М. В. Шванкова, може йти значно швидше, ніж процес формування навичок почерку. У підписі виявляється високий ступінь автоматизму, а сам підпис набуває значної стійкості. Часті повторення вдосконалюють і закріплюють навички виконання підпису (Vinberg, \& Shvankova, 1977). Тому, щоб змінити свій підпис або виконати підпис від імені іншої особи, потрібен час - специфічні для письма людини нервові зв'язки виробляються і закріплюються протягом тривалого періоду (Iablokov (Otv. red.), 2001, s. 286). Судово-доказова сила письмових актів, свого часу наголошував засновник судової експертизи документів Є. Ф. Буринський, базується на переконанні, що кожній людині належить особливий почерк, відмінний від усіх інших і здатний, у разі потреби, служити надійним визначником їі особи. Якби кожен міг вільно писати будь-яким почерком, письмові докази не мали 6 сенсу (Burinskii, 2002, s. 205).

\section{Наукова новизна}

Засновуючись на результатах проведеного авторами цієї статті експерименту, започатковано тактичний прийом подолання протидії перевірюваної особи в разі повідомлення неправдивої інформації про незнання цією особою транскрипції підпису конкретної людини, що полягає в наданні особі досліджуваного підпису для короткочасного візуального його огляду.

\section{Висновки}

За результатами дослідження можна стверджувати таке:

1. Застосування слідчим, стороною захисту та судом систем тактичних прийомів у конфліктних і безконфліктних ситуаціях під час відібрання зразків із метою одержання якісних експериментальних зразків почерку та підписів - необхідна передумова ефективного проведення судової почеркознавчої експертизи.

2. Вибір тактичних прийомів відібрання експериментальних зразків для експертного дослідження на етапі підготовки судової почеркознавчої експертизи грунтується на 
результатах прогнозування слідчої ситуації, що склалася, поведінки перевірюваної особи. Прогноз здійснюється двома способами: безпосереднім сприйняттям особистісних характеристик перевірюваної особи, під час проведення попередніх слідчих дій; опосередковано, збираючи й аналізуючи інформацію, яка характеризує особу.

3. Тактичні прийоми відібрання експериментальних зразків почерку та підписів залежно від ситуаційної обумовленості можна класифікувати: за етапами проведення (такі, що використовуються на підготовчому та робочому етапах); об’єктом впливу (перевірювана особа, почерковий матеріал); видом слідчої ситуації (сприятлива, конфліктна); характером інформації, що передається перевірюваній особі (матеріалізована, словесна); змістом (операційні, поведінкові прийоми). Сукупність тактичних прийомів створює тактичну комбінацію, метою якої є одержання репрезентативних, якісних зразків.

4. Залежно від слідчої ситуації, яка склалася, системи тактичних прийомів відібрання зразків спрямовані: на встановлення обставин та умов виконання рукопису; одержання зразків почерку перевірюваної особи в ситуації можливої ії відмови; спілкування з такою особою і вплив на неї у процесі відібрання зразків; подолання протидії перевірюваної особи.

5. Тактичні прийоми подолання протидії перевірюваного передбачають: за відмови від надання експериментальних зразків почерку та підписів - використання прийомів психологічного впливу та логічного переконання; у разі спотворення перевірюваним свого почерку - прискорення темпу написання та збільшення тривалості відібрання зразків; якщо повідомлено неправдиву інформацію про незнання перевірюваним транскрипції підпису конкретної людини - надання досліджуваного підпису для короткочасного візуального огляду. Останній прийом заснований на результатах проведеного авторами цієї статті експерименту.

Отже, реалізація викладених вище положень має позитивно вплинути на рівень тактико-криміналістичного забезпечення досудового розслідування, якісний стан діяльності слідчих із виявлення прийомів протидії перевірюваних осіб та подолання їх, посилить тактичний потенціал сторони обвинувачення, захисту та суду під час проведення судової почеркознавчої експертизи і отримання зразків почерку та підписів.

\section{References}

Arotcker, L. E. (1958). Osnovnye voprosy kriminalisticheskogo issledovaniia podpisei, vypolnennykh s podrazhaniem. Teoriia i praktika kriminalisticheskoi ekspertizy, 3, 136-179 [in Russian].

Berger, V. E., \& Sapun, A. P. (1974). Podgotovka i napravlenie materialov dlia provedeniia sudebnykh ekspertiz. Kiev: RIO MVD USSR. 78 s. [in Russian].

Belkin, R. S. (1997). Kurs kriminalistiki: v 3 t. T. 3: Kriminalisticheskie sredstva, priemy i rekomendatcii. M.: Iurist. 480 s. [in Russian].

Bird, C., Found, B., Ballantyne, K., \& Rogers, D. (2010). Forensic handwriting examiners' opinions on the process of production of disguised and simulated signatures. Forensic Science International (Vol. 195. Issues 1-3, p. 103-107). Retrieved from https://doi.org/10.1016/j.forsciint.2009.12.001.

Bird, C., \& Found, B. (2016). The modular forensic handwriting method. Journal of Forensic Document Examination (Vol. 26, p. 7-83). Retrieved from https://www.researchgate.net/publication/314116493_The_modular_forensic_handwriting_method.

Burinskii, E. F. (2002). Sudebnaia ekspertiza dokumentov, proizvodstvo ee i polzovanie eiu. M.: LeksEst. $464 \mathrm{~s}$. [in Russian].

Filkova, O. N. (2001). Spravochnik eksperta-kriminalista. M.: Iurisprudentciia. 464 s. [in Russian].

Gupta, R. R., \& Ravi, N. (2018). A successful examination of writing in giving authorship-a case study. Forensic Science \& Addiction Research (Vol. 3. Issues 1, p. 201-206). Retrieved from http://crimsonpublishers.com/ fsar/pdf/FSAR.000560.pdf. 
Huber, R., \& Headrick, A. (2017). Handwriting Identification: Facts and Fundamentals. CRC Press, New York. $420 \mathrm{p}$.

Iablokov, N. P. (Otv. red.). (2001). Kriminalistika: uchebnik. 2-e izd., pererab. I dop. M.: Iurist. 718 s. [in Russian]. Konovalova, V. E. (1981). Kriminalisticheskaia taktika: printcipy i funktcii. Kriminalistika i sudebnaia ekspertiza, 22, 40-47. [in Russian].

Konovalova, V. E., \& Shepitko, V. Iu. (1997). Kriminalisticheskaia taktika: teorii i tendentcii: ucheb. posobie. Kharkov: Grif. 256 s. [in Russian].

Komarkov, V. S. (1973). Voprosy sistematizatcii takticheskikh priemov rassledovaniia. Voprosy kriminalisticheskoi metodologii, taktiki i metodiki rassledovaniia. M.: Iurid. lit. S. 68-97 [in Russian].

Komarkov, V. S. (1975). Taktika doprosa: ucheb. posobie. Kharkov: Vyshcha shk. 64 s. [in Russian].

Komissarov, V. I. (1987). Teoreticheskie problemy sledstvennoi taktiki. Saratov: Izdatelstvo Saratov. un-ta, $156 \mathrm{s.}$ [in Russian].

Ratinov, A. R. (2001). Sudebnaia psikhologiia dlia sledovatelei. M.: Iurlitinform. 352 s. [in Russian].

Semenikhin, M. V., \& Kachurin, S. G. (2018). Protidiia zatcikavlenikh osib pri provedenni sudovo-pocherkoznavchoï ekspertizi: poniattia, formi ta priiom. Kriminalistichnii visnik, 1 (29), 96-105 [in Ukrainian].

Shabanov, V. B. (2017). Osobennosti informatcionno-kriminalisticheskikh tekhnologii. Kriminalisticheskoe obespechenie rassledovaniia prestuplenii: problemy, perspektivy i innovatcii: materialy mezhdunar. nauch-prakt. konf., posviashch. 45-letiiu kafedry kriminalistiki iurid. fak. BGU (Minsk, 12-13 okt. 2017). Minsk: Izd. tcentr BGU. S. 10-11. [in Russian].

Shepitko, V. Iu. (1985). Teoreticheskie problemy sistematizatcii takticheskikh priemov v kriminalistike. Kharkov: RIP Original. 200 s. [in Russian].

Thomas, M. W., \& Rajan, S. K. (2019). Genuine handwriting variations in 10 years: a pilot study. Egyptian Journal of Forensic Sciences (Vol. 9 (49), p. 1-7). Retrieved from https://doi.org/10.1186/s41935-019-0154-2.

Vinberg, L. A., \& Shvankova, M. V. (1997). Pocherkovedcheskaia ekspertiza: ucheb. dlia vuzov MVD SSSR. Volgograd: Volgogradskaia pravda. 174 s. [in Russian].

\section{Список використаних джерел}

Ароцкер, Л. Е. (1958). Основные вопросы криминалистического исследования подписей, выполненных с подражанием. Теория и практика криминалистической экспертизы, 3, 136-179.

Бергер, В. Е., \& Сапун, А. П. (1974). Подготовка и направление материалов для проведения судебных экспертиз. Киев: РИО МВД УССР. 78 с.

Белкин, Р. С. (1997). Курс криминалистики: в 3 т. Т. 3: Криминалистические средства, приемы и рекомендации. М.: Юристъ. 480 с.

Bird, C., Found, B., Ballantyne, K., \& Rogers, D. (2010). Forensic handwriting examiners' opinions on the process of production of disguised and simulated signatures. Forensic Science International (Vol. 195. Issues 1-3, p. 103-107). Retrieved from https://doi.org/10.1016/j.forsciint.2009.12.001.

Bird, C., \& Found, B. (2016). The modular forensic handwriting method. Journal of Forensic Document Examination (Vol. 26, p. 7-83). Retrieved from https://www.researchgate.net/publication/314116493_The_modular_forensic_handwriting_method.

Буринский, Е. Ф. (2002). Судебная экспертиза документов, производство ее и пользование ею. М.: ЛексЭст. 464 с.

Филькова, О. Н. (2001). Справочник эксперта-криминалиста. М.: Юриспруденция. 464 с.

Gupta, R. R., \& Ravi, N. (2018). A successful examination of writing in giving authorship-a case study. Forensic Science \& Addiction Research (Vol. 3. Issues 1, p. 201-206). Retrieved from http://crimsonpublishers.com/ fsar/pdf/FSAR.000560.pdf.

Huber, R., \& Headrick, A. (2017). Handwriting Identification: Facts and Fundamentals. CRC Press, New York. $420 \mathrm{p}$.

Яблоков, Н. П. (Отв. ред.). (2001). Криминалистика: учебник. 2-е изд., перераб. и доп. М.: Юристь, 718 с. Коновалова, В. Е. (1981). Криминалистическая тактика: принципы и функции. Криминалистика и судебная экспертиза, 22, 40-47.

Коновалова, В. Е., \& Шепитько, В. Ю. (1997). Криминалистическая тактика: теории и тенденции: учеб. пособие. Харьков: Гриф. 256 с.

Комарков, В. С. (1973). Вопросы систематизации тактических приемов расследования. Вопросы криминалистической методологии, тактики и методики расследования. М.: Юрид. лит. С. 68-97. 
Комарков, В. С. (1975). Тактика допроса: учеб. пособие. Харьков: Выща шк. 64 с.

Комиссаров, В. И. (1987). Теоретические проблемы следственной тактики. Саратов: Издательство Саратов. ун-та, $156 \mathrm{c.}$

Ратинов, А. Р. (2001). Судебная психология для следователей. М.: Юрлитинформ. 352 с.

Семеніхін, М. В., \& Качурин, С. Г. (2018). Протидія зацікавлених осіб при проведенні судово-почеркознавчої експертизи: поняття, форми та прийом. Криміналістичний вісник, 1 (29), 96-105.

Шабанов, В. Б. (2017). Особенности информационно-криминалистических технологий. Криминалистическое обеспечение расследования преступлений: проблемы, перспективы и инновации: материалы междунар. науч-практ. конф., посвящ. 45-летию кафедры криминалистики юрид. фак. БГУ (Минск, 12-13 окт. 2017). Минск: Изд. центр БГУ. С. 10-11.

Шепитько, В. Ю. (1985). Теоретические проблемы систематизации тактических приемов в криминалистике. Харьков: РИП Оригинал. 200 с.

Thomas, M. W., \& Rajan, S. K. (2019). Genuine handwriting variations in 10 years: a pilot study. Egyptian Journal of Forensic Sciences (Vol. 9 (49), p. 1-7). Retrieved from https://doi.org/10.1186/s41935-019-0154-2.

Винберг, Л. А., \& Шванкова, М. В. (1997). Почерковедческая экспертиза: учеб. для вузов МВД СССР. Волгоград: Волгоградская правда. 174 с.

Стаття надійшла до редакції 28.04.2020

\author{
S. Kachurin, Ph.D in Law, Associate Professor, \\ Associate Professor of Constitutional Law Department, \\ Volodymyr Dahl East Ukrainian National University, \\ Sievierodonetsk, Luhansk region, Ukraine \\ M. Semenikhin, Head, \\ Luhansk Scientific Research Forensic Center, MIA of Ukraine, \\ Rubizhne, Luhansk region, Ukraine
}

\title{
OVERCOMING OF COUNTERFEIT DURING THE FORENSIC HANDWRITING EXAMINATION: SYSTEMS OF TACTICAL TECHNIQUES
}

\begin{abstract}
The purpose of the article is to analyze theoretical issues and develop practical recommendations on the tactics of taking experimental handwriting and signature samples in the face of the tested persons during forensic handwriting examinations. Methodology. The methodological basis is the general laws and categories of the theory of cognition, in particular the provisions of the materialist dialectic on the cognition of social processes and phenomena associated with the studied problems. In the process of consideration of the topic were also used: historical and legal method, which analyzed the genesis of the development of tactical and technological principles of investigative actions, theoretical developments in forensic aspects of counteraction in forensic handwriting examinations; system, structural and comparative methods establish the essence of tactics of forensic handwriting examinations, clarify the methods of overcoming the opposition of the inspected persons to handwriting examination, as well as grouping them into systems, offer recommendations for their use; the sociological method (questionnaire) was used to interview investigators and experts on a specially designed questionnaire; statistical method (grouping of information, analysis of quantitative indicators) summarizes the data on the results of the analysis of expert opinions, protocols for sampling handwriting and signatures; experiments on the reproduction of other people's signatures by different categories of persons were carried out experimentally. The scientific novelty arises due to the beginning of the results of the experiment conducted by the authors of the tactical method of overcoming the opposition of the inspected person in case of false information about this person's ignorance of transcription of a particular person's signature, which is to provide the subject with a short signature. Conclusions. As a result of the research, in particular, it was found that, depending on the current investigative situation, the system of tactical methods of sampling is aimed at: establishing
\end{abstract}


the circumstances and conditions of the manuscript; obtaining samples of handwriting of the inspected person in the situation of his possible refusal; communication with such a person and influence on him in the process of sampling; overcoming the opposition of the inspected person. Thus tactical methods of overcoming of opposition of the checked person provide: for refusal to provide experimental samples of handwriting and signatures - the use of methods of psychological influence and logical persuasion; in case of distortion of the inspected person of his/her handwriting - acceleration of a rate of writing and increase in duration of sampling; if false information is reported about the inspected person's ignorance of the transcription of the signature of a particular person - providing the subject's signature for a short-term visual inspection.

Keywords: forensic handwriting examination; samples of handwriting and signatures; tactics and technology of sampling; opposition to forensic handwriting examination; forecasting the investigative situation; systems of tactics; psychological contact; modeling of circumstances and conditions of sampling.

\title{
С. Г. Качурин, кандидат юридических наук, дочент,
}

дочент кафедры конституиионного права,

Восточноукраинский национальный

университет им. Владимира Даля,

2. Северодонеик, Луганская обл.

М. В. Семенихин, директор,

Луганский научно-исследовательский

экспертно-криминалистический иентр МВД Украинь,

2. Рубежное, Луганская обл.

\section{ПРЕОДОЛЕНИЕ ПРОТИВОДЕЙСТВИЯ ПРИ ПРОВЕДЕНИИ СУДЕБНОЙ ПОЧЕРКОВЕДЧЕСКОЙ ЭКСПЕРТИЗЫ: СИСТЕМЫ ТАКТИЧЕСКИХ ПРИЕМОВ}

\begin{abstract}
Цель статьи - анализ теоретических вопросов и разработка практических рекомендаций по тактике отбора экспериментальных образцов почерка и подписей в условиях противодействия проверяемых лиц при проведении судебных почерковедческих экспертиз. Методология. Методологическую основу составляют основные законы и категории теории познания, в частности положения материалистической диалектики о познании социальных процессов и явлений, связанных с исследуемыми проблемами. В процессе рассмотрения темы также применялись историко-правовой метод, при помощи которого проанализирован генезис разработки тактико-технологических основ проведения следственных действий, теоретические выкладки криминалистических аспектов противодействия при проведении судебных почерковедческих экспертиз; системно-структурным и сравнительным раскрыта суть тактики проведения судебных почерковедческих экспертиз; найдены приемы преодоления противодействия проверяемых лиц проведению почерковедческой экспертизы, а также группирование их в системы, предложены рекомендации относительно их применения; социологический метод (анкетирование) применен для опроса следователей и экспертов по специально разработанной анкете; статистическим методом (группирование сведений, анализ количественных показателей) обобщены данные по результатам анализа выводов экспертов, протоколов отбора образцов почерка и подписей; экспериментальным проведены эксперименты по воспроизведению чужих подписей разными категориями лиц. Научная новизна обусловлена обоснованием применения основанного на результатах проведенного авторами эксперимента тактического приема преодоления противодействия проверяемого лица в случае сообщения неправдивой информации о незнании этим лицом транскрипции подписи конкретного человека, заключающегося в предоставлении лицу исследуемой подписи для кратковременного визуального ее осмотра. Bbıюды. В результате исследования, в частности, выяснено, что в зависимости от сложившейся следственной ситуации системы тактических приемов отбора образцов направлены: на установление обстоятельств и условий исполнения рукописи; получение образцов почерка проверяемого лица в ситуации возможного его отказа; общение с таким лицом и влияние
\end{abstract}


на него в процессе отбора образцов; преодоление противодействия проверяемого лица. При этом тактические приемы преодоления противодействия проверяемого лица предусматривают: в случае отказа от представления экспериментальных образцов почерка и подписей - использование приемов психологического влияния и логического убеждения; при искажении проверяемым своего почерка - ускорение темпа написания и увеличение продолжительности отбора образцов; если сообщена ложная информация о незнании проверяемым транскрипции подписи конкретного человека - предоставление исследуемой подписи для кратковременного визуального ее осмотра.

Ключевые слова: судебная почерковедческая экспертиза; образцы почерка и подписей; тактика и технология отбора экспериментальных образцов; противодействие проведению судебной почерковедческой экспертизы; прогнозирование следственной ситуации; системы тактических приемов; психологический контакт; моделирование обстоятельств и условий отбора экспериментальных образцов почерка и подписей. 